\title{
Estimation of Non-Point Source Pollution Load of the Livestock and Poultry Breeding in Sichuan Province, China
}

\author{
Feng Wang \\ College of Civil Engineering \\ Sichuan Agricultural University \\ Chengdu, China \\ wf20126467@163.com \\ Pingjing Gui \\ College of Civil Engineering \\ Sichuan Agricultural University \\ Chengdu, China \\ gpjmututu@163.com
}

\author{
Likou Zou \\ College of Tourism \\ Sichuan Agricultural University \\ Chengdu, China \\ zoulk124@163.com \\ Liangqian Fan \\ College of Civil Engineering \\ Sichuan Agricultural University \\ Chengdu, China \\ flqjacky@,163.com
}

\begin{abstract}
The study was to estimate the livestock and poultry breeding (LPB) non-point source pollution load in Sichuan province and provide support for control of LPB non-point source pollution. In the study, an improved export coefficient method was proposed to estimate LPB non-point source pollution loads from the stages of generation, discharge and export. Based on the established model, total nitrogen (TN), total phosphorus (TP) and chemical oxygen demand (COD) loads of LPB non-point source pollution were estimated in $\mathbf{2 1}$ administrative institutions of Sichuan province in 2012. The results indicated that the generation, discharge and export loads of TN, TP, and COD in Sichuan province were 421860.34 $\mathrm{t}, 73183.22 \mathrm{t}$ and $7192384.64 \mathrm{t}$, 169302.65 $t, 23737.94 t$ and $3228082.48 t$, and $97086.62 t$, $13620.3 \mathrm{t}$ and $1861604 \mathrm{t}$, respectively. In 21 administrative institutions, Aba was the maximum per area generation loads region of TN, TP and COD, while Suining was the region in which the surface water pollution caused by $T N$, TP and COD from LPB was the most serious. The results show that LPB non-point source pollution in some areas of Sichuan province are serious and controlling LBP non-point source pollution should to be attached importance.
\end{abstract}

Keywords-livestock and poultry breeding; non-point source pollution load; TN; TP; COD

\section{INTRODUCTION}

In recent years, LPB has been the major source of agricultural non-point source pollution with the increasing demand of livestock and poultry products in China. For its pollution control, estimation and evaluation studies on LPB non-point source pollution load have been the basic work. In the study area, a lot of methods can be used, for example transport coefficient model [1], SWAT [2], inventory method [3] and export coefficient model [4]. In all methods, export coefficient model was regarded as a simple and convenient model and had been applied in many areas.
To the end of 2012, output value of animal husbandry in Sichuan province was $¥ 226.986$ billion, accounting for $41.8 \%$ of gross output value of agriculture [5]. However, there is lack of systemic research of LPB non-point source pollution in Sichuan province. The objective of the study was to estimate the LPB non-point source pollution load in Sichuan province in 2012 and provide support for control of LPB non-point source pollution.

\section{MATERIALS AND METHOD}

\section{A. Study area}

Sichuan is located in the southwest of China and contains 21 administrative institutions. The cultivated field was $39910 \mathrm{~km}^{2}$ and surface water resource was 292.1 billion $\mathrm{m}^{3}$. In 2012 , the annual slaughter of pig, cattle, sheep, poultry and rabbit was 91.94 million, 3.04 million, 19.16 million, 988.98 million, and 100.32 million, respectively. The other used data of 21 administrative institutions can refer to reference [5].

\section{B. Methods}

\section{1) Study framework}

In this study, formation progress of LPB non-point source pollution load was divided to three processes, namely generation process, discharge process and export process. The research technical route is shown in Figure 1.

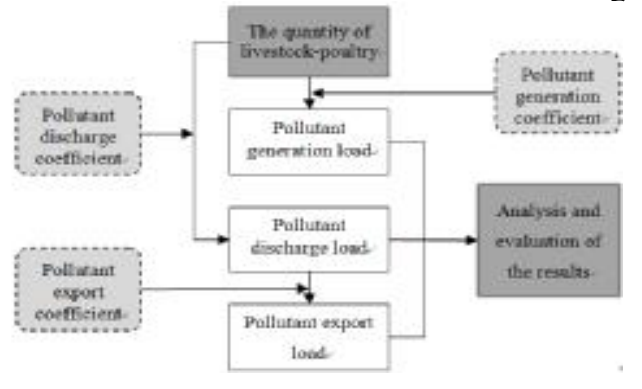

Figure 1. The research technical route 


\section{2) Estimation model}

Depending on the export coefficient model, an improved LPB non-point source pollution load estimation model was established from the stages of generation, discharge and export as follows:

a) The pollutant generation model

$$
T_{i}=Q_{j} \cdot P_{j} \cdot E_{i j} \cdot 10^{-6}
$$

Where $T_{i}$ is the total LPB pollutant generation load of ith pollutant $\left(\mathrm{t}^{\cdot} \mathrm{y}^{-1}\right) ; Q_{j}$ is the quantity of livestock and poultry (capita) (Table I); $P_{j}$ is the breeding cycle of this kind of livestock and poultry (d). The breeding cycle of cattle, sheep, pig, poultry and rabbit is $365 \mathrm{~d}, 365 \mathrm{~d}, 150 \mathrm{~d}$, $60 \mathrm{~d}$ and $90 \mathrm{~d}$, respectively. $E_{i j}$ refers to LPB pollutant generation coefficient $\left(\mathrm{g} \cdot\right.$ capita $\left.^{-1} \cdot \mathrm{d}^{-1}\right)$ (Table II).

TABLE I. THE QUANTITY OF LIVESTOCK AND POULTRY IN SICHUAN IN $2012\left(10^{4}\right.$ CAPITA) $[5,6]$

\begin{tabular}{|c|c|c|c|c|c|}
\hline Unit & Pig & Cattle & Sheep & Poultry & Rabbit \\
\hline Chengdu & 1095.30 & 5.7947 & 60.1620 & 11270.4140 & 648.7421 \\
\hline Zigong & 279.54 & 6.4900 & 157.1700 & 4309.6200 & 2755.0900 \\
\hline Panzhihua & 67.91 & 4.0400 & 37.9100 & 610.6400 & - \\
\hline Luzhou & 494.00 & 11.6000 & 67.2000 & 5756.0000 & 55.9900 \\
\hline Deyang & 450.00 & 14.1000 & 33.9000 & 11600.0000 & 183.0000 \\
\hline Mianyang & 590.00 & 1.3000 & 5.2100 & 1286.6700 & 5.5000 \\
\hline Guangyuan & 399.80 & 10.4000 & 48.6536 & 2874.5200 & 690.0000 \\
\hline Suining & 481.69 & 9.7700 & 71.3400 & 3338.5000 & - \\
\hline Neijiang & 423.78 & 1.3588 & 33.5500 & 4517.5500 & 470.5000 \\
\hline Leshan & 382.79 & 7.2772 & 8.4810 & 5825.6800 & 867.2000 \\
\hline Nanchong & 784.69 & 20.6400 & 268.9800 & 3135.0000 & 612.7300 \\
\hline Meishan & 35.07 & 1.5700 & - & 4712.0100 & 1984.3100 \\
\hline Yibin & 597.78 & 9.4767 & 71.4300 & 19379.9300 & 976.3800 \\
\hline Guang'an & 537.70 & 7.4500 & 54.6400 & 4856.8000 & 470.2000 \\
\hline Dazhou & 318.09 & 20.1200 & 73.9700 & 5974.2100 & 41.5000 \\
\hline Ya'an & 148.15 & 9.7700 & 33.2900 & 1648.8800 & 100.7085 \\
\hline Bazhong & 533.76 & 16.1100 & 88.6900 & 748.0000 & 8.9200 \\
\hline Ziyang & 700.90 & 5.0700 & 301.9600 & 4267.3600 & 97.7200 \\
\hline Aba & 38.17 & 55.2800 & 43.1800 & 36.1515 & 63.2252 \\
\hline Ganzi & 223.10 & 40.3106 & 24.5099 & - & - \\
\hline Liangshan & 612.15 & 45.6200 & 431.6400 & 2749.7700 & - \\
\hline “"”indictes that the qunty 0 fthis kind 1 fivestock & & \\
\hline
\end{tabular}

"-" indicates that the quantity of this kind of livestock and poultry has not been announced.

TABLE II. POLLUTANT GENERATION COEFFICIENT OF LPB [8-12]

\begin{tabular}{|c|c|c|c|}
\hline $\begin{array}{l}\text { Livestock and } \\
\text { poultry species }\end{array}$ & $\begin{array}{c}\text { TN } \\
\left(\text { g. } \text { capita }^{-1} \cdot \mathbf{d}^{-1}\right)\end{array}$ & $\begin{array}{c}\text { TP } \\
(\text { g. capita } \\
\left.\text { cap }^{-1} \cdot \mathbf{d}^{-1}\right)\end{array}$ & $\begin{array}{c}\text { COD } \\
\left(\text { g. } \text { capita }^{-1} \cdot \mathbf{d}^{-1}\right)\end{array}$ \\
\hline Pig & 15.355 & 3.39 & 272.845 \\
\hline Cattle & 104.10 & 10.17 & 2235.21 \\
\hline Sheep & 6.247 & 1.233 & 12.055 \\
\hline Poultry & 0.71 & 0.06 & 13.05 \\
\hline Rabbit & 0.99 & 0.33 & 10.44 \\
\hline
\end{tabular}

b) The pollutant discharge model

$$
L_{i}=Q_{j} \cdot P_{j} \cdot R_{i j} \cdot 10^{-6}
$$

Where $L_{i}$ is the total LPB pollutant discharge load of the $\mathrm{i}$ th pollutant $\left(\mathrm{t} \cdot \mathrm{y}^{-1}\right) ; R_{i j}$ refers to LPB pollutant discharge coefficient $\left(\mathrm{g} \cdot\right.$ capita $\left.^{-1} \cdot \mathrm{d}^{-1}\right)$ (Table III).
TABLE III. POLLUTANT DISCHARGE COEFFICIENT OF LPB [8-12]

\begin{tabular}{|c|c|c|c|}
\hline $\begin{array}{c}\text { Livestock and } \\
\text { poultry species }\end{array}$ & $\begin{array}{c}\text { TN } \\
\left(\mathbf{g} \cdot \text { capita }^{-\mathbf{1}} \cdot \mathbf{d}^{-\mathbf{1}}\right)\end{array}$ & $\begin{array}{c}\text { TP } \\
\left(\mathbf{g} \cdot \text { capita }^{\mathbf{- 1}} \cdot \mathbf{d}^{\mathbf{- 1}}\right)\end{array}$ & $\begin{array}{c}\text { COD } \\
\left(\mathbf{g} \cdot \mathbf{c a p i t a}^{\mathbf{- 1}} \cdot \mathbf{d}^{\mathbf{- 1}}\right)\end{array}$ \\
\hline Pig & 7.19 & 0.94 & 110.275 \\
\hline Cattle & 34.90 & 3.91 & 931.20 \\
\hline Sheep & 2.186 & 0.432 & 4.219 \\
\hline Poultry & 0.22 & 0.04 & 10.41 \\
\hline Rabbit & 0.347 & 0.116 & 3.132 \\
\hline
\end{tabular}

c) The pollutant export model

$$
I_{i}=L_{i} \cdot C
$$

Where $I_{i}$ is the total LPB pollutant export load of the ith pollutant $\left(\mathrm{t} \cdot \mathrm{y}^{-1}\right) ; C$ is the pollutant export coefficient. Pollutant export coefficient of livestock and poultry waste is associated with local rainfall, local topography and the distance between the area of pollutant producing and the river. Firstly, in terms of the distance between the area of pollutant producing and the river, estimation units were grouped into two classes of A and B. A is on behalf of the units which possess main streams or tributaries. B refers to the units which possess the secondary tributaries. The basis pollutant export coefficient of $\mathrm{A}$ and $\mathrm{B}$ is $30 \%$ and $25 \%$. Secondly, the basis pollutant export coefficient was revised in teams of the local rainfall and topography. Correction factor to the basis pollutant export coefficient is shown in Table IV and Table V. Finally, pollutant export coefficient of livestock and poultry waste was confirmed.

TABLE IV. TERRAIN CORRECTION COEFFICIENT TO POLLUTANT EXPORT COEFFICIENT

\begin{tabular}{|c|c|c|}
\hline Type & $\begin{array}{c}\text { Correction } \\
\text { coefficient }\end{array}$ & \multicolumn{1}{c|}{ Unit and category } \\
\hline plain & 1.0 & \multicolumn{1}{c|}{ Chengdu (A) } \\
\hline hill & 1.2 & $\begin{array}{l}\text { Zigong(A), Luzhou(A), Deyang(B), } \\
\text { Mianyang(B), Guangyuan(A), } \\
\text { Suining(B), Neijiang(A), } \\
\text { Nanchong(A), Meishan(A), } \\
\text { Guang'an(A), Ziyang(A) }\end{array}$ \\
\hline $\begin{array}{c}\text { mountainous } \\
\text { region }\end{array}$ & 1.5 & $\begin{array}{l}\text { Panzhihua(A), Leshan(A), Yibin(A), } \\
\text { Dazhou(B), Ya'an(B), Bazhong(B), } \\
\text { Aba(A), Ganzi(A), Liangshan(A), }\end{array}$ \\
\hline
\end{tabular}

TABLE V. PRECIPITATION CORRECTION COEFFICIENT TO POLLUTANT EXPORT COEFFICIENT

\begin{tabular}{|c|c|c|}
\hline Type & $\begin{array}{r}\text { Correction } \\
\text { coefficient }\end{array}$ & Unit \\
\hline $600-700 \mathrm{~mm}$ & 1.1 & Chengdu \\
\hline $700-800 \mathrm{~mm}$ & 1.2 & Panzhihua, Mianyang, Ganzi \\
\hline $800-900 \mathrm{~mm}$ & 1.3 & Deyang \\
\hline $900-1000 \mathrm{~mm}$ & 1.4 & Guangyuan, Meishan, Aba \\
\hline $1000-1100 \mathrm{~mm}$ & 1.5 & Zigong, Suining, Guang'an, Ziyang \\
\hline $1100-1200 \mathrm{~mm}$ & 1.6 & Nanchong, Dazhou, Bazhong \\
\hline $1200-1300 \mathrm{~mm}$ & 1.7 & Neijiang, Yibin, Liangshan \\
\hline $1300-1400 \mathrm{~mm}$ & 1.8 & Luzhou, Leshan \\
\hline $1700-1800 \mathrm{~mm}$ & 2.2 & Ya’an \\
\hline
\end{tabular}

III. RESULTS AND DISCUSSION

\section{A. Pollutant generation loads of $L P B$}

According to the equation (1), TN, TP and COD generation loads of LPB were estimated in each unit in Table VI (column 2). The total generation loads of TN, TP, and COD was $421860.34 \mathrm{t}, 73183.22 \mathrm{t}$ and $7192384.64 \mathrm{t}$, respectively. In Sichuan province, the maximum of TN, TP and COD loads appeared in Liangshan, which accounted 
for $10 \%, 9 \%$ and $9 \%$ of total pollutant generation loads of Sichuan, while the minimum generation loads appeared in Panzhihua.

According generation loads of LPB and cultivated field areas in each administrative institution in 2012, per area pollutant generation loads of TN, TP and COD were calculated (Figure 2). In Fig. 2, it can be found that per area TN, TP and COD generation loads of Aba were the maximum, which were $381.70 \mathrm{~kg} \cdot \mathrm{hm}^{-2}, 40.94 \mathrm{~kg} \cdot \mathrm{hm}^{-2}$ and
$7810.34 \mathrm{~kg} \cdot \mathrm{hm}^{-2}$, respectively. The annual per hectare limited load of TN and TP was $170 \mathrm{~kg}$ and $35 \mathrm{~kg}[11,13]$. In Sichuan province, per area TN loads of Aba and Ganzi were over the limited level, while per area TP loads of Aba was over the limited level. In Aba, per area TN load was 2.25 times than the limited level, while per area TP load was 1.17 times than the limited level.

TABLE VI. TOTAL POLLUTION LOAD OF LPB IN STAGES OF GENERATION, DISCHARGE AND EXPORT IN SICHUAN PROVINCE IN 2012 (T)

\begin{tabular}{|c|c|c|c|c|c|c|c|c|c|}
\hline \multirow{2}{*}{ Unit } & \multicolumn{3}{|c|}{ Generation } & \multicolumn{3}{|c|}{ Discharge } & \multicolumn{3}{|c|}{ Export } \\
\hline & $T N$ & $T P$ & $C O D$ & $T N$ & $T P$ & $C O D$ & $T N$ & $T P$ & $C O D$ \\
\hline Chengdu & 34180.29 & 6653.87 & 592536.94 & 14721.29 & 2060.15 & 274021.94 & 4858.03 & 679.85 & 90427.24 \\
\hline Zigong & 16778.88 & 3343.12 & 233902.16 & 6524.90 & 1125.66 & 105402.39 & 3523.44 & 607.86 & 56917.29 \\
\hline Panzhihua & 4223.74 & 687.88 & 67203.14 & 1630.13 & 227.84 & 29362.48 & 880.27 & 123.03 & 15855.74 \\
\hline Luzhou & 19819.86 & 3468.86 & 345369.35 & 8118.92 & 1112.04 & 158285.42 & 5261.06 & 720.60 & 102568.95 \\
\hline Deyang & 21599.76 & 3436.17 & 393244.55 & 8508.21 & 1186.69 & 195851.31 & 3318.20 & 462.81 & 76382.01 \\
\hline Mianyang & 14754.95 & 3119.81 & 262429.44 & 6741.88 & 890.12 & 110144.19 & 2427.08 & 320.44 & 39651.91 \\
\hline Guangyuan & 16108.74 & 2946.41 & 279605.24 & 6619.77 & 929.88 & 122128.73 & 3336.37 & 468.66 & 61552.88 \\
\hline Suining & 17855.65 & 3253.31 & 306128.24 & 7449.47 & 1011.23 & 134835.47 & 3352.26 & 455.05 & 60675.96 \\
\hline Neijiang & 13385.69 & 2658.72 & 225794.63 & 5754.50 & 827.36 & 104776.42 & 3521.76 & 506.35 & 64123.17 \\
\hline Leshan & 15029.49 & 2722.07 & 270171.12 & 6162.88 & 887.32 & 127014.84 & 4991.93 & 718.73 & 102882.02 \\
\hline Nanchong & 33930.46 & 6261.69 & 531679.48 & 13843.45 & 1964.31 & 225400.91 & 7973.83 & 1131.44 & 129830.92 \\
\hline Meishan & 5179.63 & 995.58 & 82701.50 & 1819.91 & 392.11 & 46161.85 & 917.23 & 197.62 & 23265.57 \\
\hline Yibin & 28123.7 & 4700.62 & 486029.63 & 11087.25 & 1657.80 & 255989.69 & 8481.75 & 1268.22 & 195832.11 \\
\hline Guang'an & 18949.14 & 3571.15 & 325695.03 & 7972.02 & 1116.29 & 146766.35 & 4304.89 & 602.80 & 79253.83 \\
\hline Dazhou & 19239.92 & 2924.65 & 344755.98 & 7385.34 & 1000.00 & 159572.51 & 4431.21 & 600.00 & 95743.51 \\
\hline Ya'an & 8675.74 & 1355.10 & 155663.46 & 3357.07 & 450.90 & 68808.35 & 2769.58 & 371.99 & 56766.88 \\
\hline Bazhong & 20763.93 & 3740.9 & 359727.4 & 8617.94 & 1141.25 & 149109.45 & 5170.77 & 684.75 & 89465.67 \\
\hline Ziyang & 26860.02 & 5293.88 & 375837.34 & 11208.17 & 1649.37 & 164749.31 & 6052.41 & 890.66 & 88964.63 \\
\hline Aba & 22939.92 & 2460.52 & 469401.62 & 7822.55 & 918.30 & 195272.85 & 4928.21 & 578.53 & 123021.89 \\
\hline Ganzi & 21014.03 & 2741.12 & 421260.73 & 7736.66 & 928.51 & 174291.86 & 4177.80 & 501.40 & 94117.60 \\
\hline Liangshan & 42446.81 & 6847.79 & 663247.81 & 16220.32 & 2260.80 & 280136.21 & 12408.55 & 1729.51 & 214304.20 \\
\hline
\end{tabular}

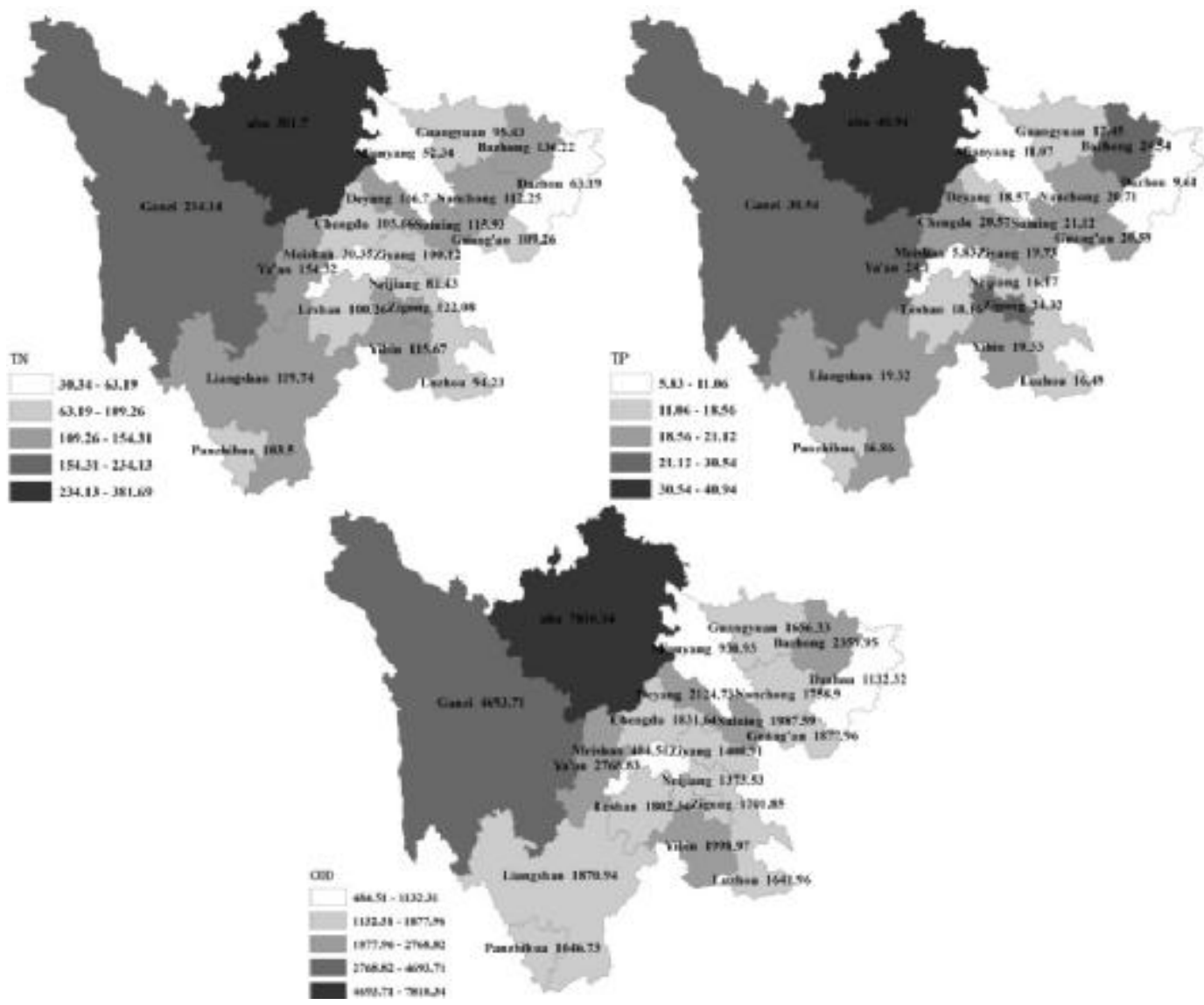

Figure 2. Per area generation loads of TN, TP and COD in Sichuan province $\left(\mathrm{kg} \cdot \mathrm{km}^{-2}\right)$ 


\section{B. Pollutant discharge load of $L P B$}

According to the equation (2), TN, TP and COD discharge loads of LPB were estimated in each unit in Table VI (column 3). The total pollutant discharge loads of TN, TP, and COD in Sichuan province were 169302.65 t, $23737.94 \mathrm{t}$ and $3228082.48 \mathrm{t}$, which were $40 \%, 32 \%$, and $45 \%$ of the total pollutant generation loads, respectively. Among 21 units, TN, TP and COD discharge loads of Liangshan were the maximum, which accounted for $10 \%$, $10 \%$ and $9 \%$ of total pollutant discharge loads of Sichuan province.

\section{Pollutant export load of $L P B$}

According to the equation (3), TN, TP and COD export loads of LPB were estimated in each unit in Table VI (column 4). The total export loads of TN, TP, and COD in Sichuan province were 97086.62 t, $13620.3 \mathrm{t}$ and 1861604 t. In 21 units, TN, TP and COD export loads of Liangshan were the maximum, which accounted for $13 \%, 13 \%$ and $12 \%$ of total pollutant export loads of Sichuan province.

The ratio of the export loads and the quantity of surface water resource can be used to describe the surface water pollution degree caused by LPB. Figure 3 showed that the ratios of TN, TP and COD in 21 units. As shown in Fig. 3, the ratios in east of Sichuan province were larger than those in west of Sichuan province. In all 21 units, Suining was the region in which surface water pollution caused by TN, TP and COD from LPB was the most serious.

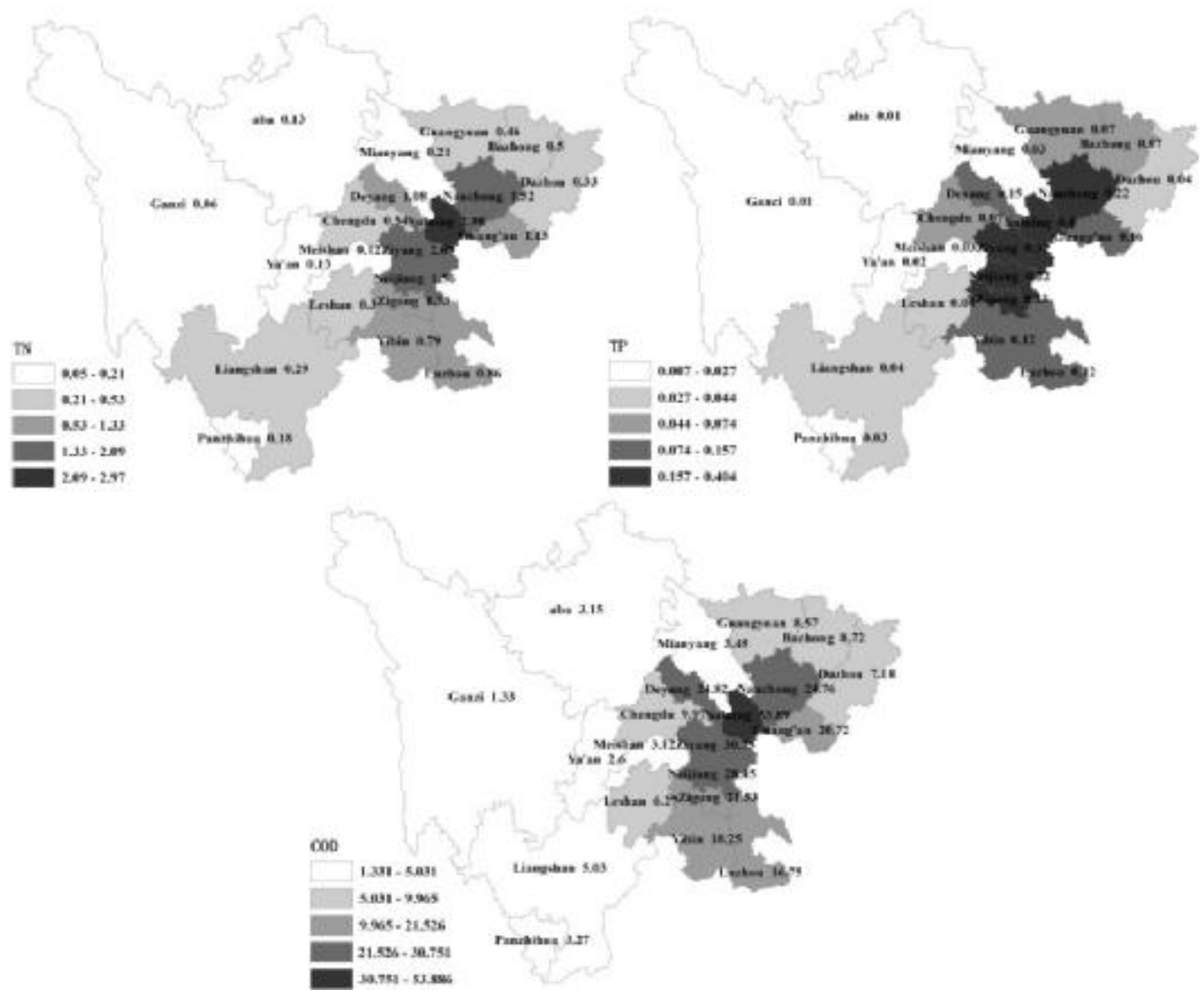

Figure 3. The ratios of export loads and quantity of surface water resource in Sichuan province $\left(\mathrm{mg} \cdot \mathrm{L}^{-1}\right)$

\section{CONCLUSION}

In the study, TN, TP and COD loads of LPB of Sichuan province in 2012 were estimated from the stages of generation, discharge and export. The generation, discharge and export loads of TN, TP, and COD were $421860.34 \mathrm{t}, 73183.22 \mathrm{t}$ and $7192384.64 \mathrm{t}, 169302.65 \mathrm{t}$, $23737.94 \mathrm{t}$ and $3228082.48 \mathrm{t}$, and $97086.62 \mathrm{t}, 13620.3 \mathrm{t}$ and $1861604 \mathrm{t}$, respectively. In three processes, Liangshan had the maximum TN, TP and COD loads. In 21 administrative institutions of Sichuan province, Aba was the maximum per area generation loads region of TN, TP and COD, while Suining was the region in which surface water pollution caused by TN, TP and COD from LPB was the most serious. Therefore, Aba and Suining were the critical regions of LPB non-point source pollution control. In Sichuan province, controlling LBP non-point source pollution should to be attached importance with the development of LPB industry.

\section{ACKNOWLEDGMENT}

The research work was supported by the Scientific Research Fund of Sichuan Provincial Education Department under Grant No.2014ZA0004. 


\section{REFERENCES}

[1] A. Katip and F. Karaer, "Research on the non-point pollution loads in the lake uluabat basin," Journal of Environmental Protection, vol. 4, July 2013, pp.29-37, doi:10.4236/jep.2013.47A004.

[2] G. Vazquez-amabile, B.A. Engel and D.C. Flanagan, "Modeling and risk analysis of nonpoint-source pollution caused by atrazine using SWAT," Transactions of the ASAE, vol. 49, May-June 2006, pp.667-678, doi:10.1.1.548.3467.

[3] L. Zhou, J.G. Xu, D.Q. Sun and T.H. Ni, "Spatial heterogeneity and classified control of agricultural non-point source pollution in Huaihe river basin," Environmental Science, vol. 34, February 2013, pp.547-554, doi:10.3969/j.issn. 0250-3301.2013.02.20.

[4] Y.Q. Liu, Y.L. Yang and F.H. Li, "Estimation of pollution loads from agricultural nonpoint sources in Beijing region based on export coefficient modeling approach," Transactions of the CSAE, vol. 27, July 2011, pp.7-12, doi: 10.3969/j.issn.10026819.2011.07.002

[5] Sichuan provincial bureau of statistics, Sichuan statistical yearbook. Beijing, China: Statistics Press, 2013.

[6] Sichuan provincial people's government office, Rural yearbook of Sichuan. Chengdu, China: University of Electronic Science and Technology Press, 2013.

[7] Q.T. Ma and B.Q. Wang, "Estimation of non-point source pollution loads in Tianjin Binhai new area," Journal of Safety and Environment, vol. 11, April 2011, pp.142-147, doi:10.3969/j.issn.1009-6094.2011.02.033.
[8] The board of the first national pollution source census, Generation and discharge coefficient manual of livestock and poultry breeding source pollution. Beijing, China: Environmental Science Press, 2011.

[9] J.K. Ye, "Feeding and management techniques of nursing piglets. Livestock and Poultry Industry," vol. 22, July 2012, pp.42, doi:10.3969/j.issn.1008-0414.2012.07.050.

[10] X.R. Zhang, B.S. Huang, G.Y. Du, W.D. Zheng, C.Q. Mao and D.Q. Cai, "Investigation and preventive measures on animal husbandry pollution in Chengdu city," Acta Ecologiae Animalis Domastici, vol. 32, November 2011, pp.108-115, doi:10.3969/j.issn.1673-1182.2011.06.025.

[11] F.H. Wang, W.Q. Ma, Z.X. Dou, L. Ma, X.L. Liu, J.X. Xu and F.S. Zhang, "The estimation of the production amount of animal manure and its environmental effect in China," China Environment Science, vol. 26, May 2006, pp.614-617, doi:10.3321/j.issn:10006923.2006.05.024

[12] J. Lu, "Calculate the water environment capacity of surface water in Hangzhou base on GIS," unpublished.

[13] F. Yang, S.Q. Yang, Y.Q. Zhu and J.L. Wang, "Analysis on livestock and poultry production and nitrogen pollution load of cultivated land during last 30 years in China," Transactions of the Chinese Society of Agricultural Engineering, vol. 29, March 2013 , pp.1-11, doi: 10.3969/j.issn.1002-6819.2013.05.001 